\title{
Aligning academic research and Science, Technology, and Innovation (ST\&I): a proposal using Design Science
}

\author{
DONIZETI LEANDRO DE SOUZA ${ }^{12}$ \\ THAIS ASSIS DE SOUZA ${ }^{13}$ \\ ANDRE LUIZ ZAMBALDE ${ }^{1}$ \\ ${ }^{1}$ UniVersidAde Federal de LAVRAS (UFLA), LAVRAS - MG, BRAZIL \\ ${ }^{2}$ Instituto federal de Educação, CiênCia e TeCnologia do Sul de Minas Gerais (IFSUldeminAS), Pouso Alegre - MG, Brazil \\ ${ }^{3}$ UnIVERSITY PARIS-SACLAY / CENTRALESUPÉLEC, GIF-SUR-YVETTE, FRANCE
}

\begin{abstract}
Universities have been criticized for the lack of integration of academic research with societies' demands. This theoretical essay reflects on the use of the Design Science approach to align academic research with activities of science, technology, and innovation (ST\&l) addressing societal needs. The study presents a theoretical background on new forms of evaluation of academic research and on the foundations of Design Science in relation to other research approaches, highlighting its ontological, epistemological, methodological, and axiological assumptions. Finally, we present a conceptual model of Design Science and its potential utility for new forms of scientific and technological production, considering the cycles of relevance, design, and rigor. We also highlight the importance of the Design Science Research (DSR) in conducting result-oriented studies. Such a perspective can foster new reflections and debates in the academic field about alternative ways to develop and evaluate scientific and technological research.
\end{abstract}

Keywords: Design Science. ST\&I. Academic research. University. Innovation.

\section{Pesquisa acadêmica e avanços em Ciência, Tecnologia e Inovação(CT\&I): uma proposta de aproximação pela Design Science}

\section{Resumo}

Diversas críticas têm sido atribuídas às universidades pela falta de integração das pesquisas acadêmicas com as demandas da sociedade. Assim, o objetivo deste ensaio teórico é refletir sobre a utilização da Design Science como abordagem capaz de contribuir para uma aproximação das pesquisas acadêmicas com as atividades de Ciência, Tecnologia e Inovação (CT\&l), alinhando os esforços da academia às necessidades da sociedade. Para tanto, é apresentado um background teórico sobre novas formas de avaliação da pesquisa acadêmica, assim como os fundamentos da Design Science em relação aos de outras abordagens de pesquisa, destacando seus pressupostos ontológicos, epistemológicos, metodológicos e axiológicos. Por fim, são apresentados um modelo conceitual da Design Science e sua potencial utilidade para novas formas de produção científica e tecnológica, considerando os ciclos de relevância, design e rigor e ressaltando a importância do método Design Science (DSR) na condução de pesquisas orientadas pelo uso dos resultados. Tal perspectiva pode despertar novas reflexões e debates no ambiente acadêmico sobre formas alternativas para o desenvolvimento e a avaliação de pesquisas científicas e tecnológicas.

Palavras-chave: Design Science. CT\&I. Pesquisa acadêmica. Universidade. Inovação.

\section{Investigación académica y avances en ciencia, tecnología e innovación(CT\&I): una propuesta de aproximación por la design science}

\section{Resumen}

Varias críticas han sido atribuidas a las universidades por la falta de integración de la investigación académica con las demandas de la sociedad. El objetivo de este ensayo teórico es reflexionar sobre el uso de la design science como un enfoque capaz de contribuir a una aproximación de la investigación académica con actividades relacionadas con ciencia, tecnología e innovación (CT\&l), alineando los esfuerzos de la academia con las necesidades de la sociedad. Para esto, se presenta una base teórica sobre nuevas formas de evaluación de la investigación académica, así como los fundamentos de la design science en relación con otros enfoques de investigación, destacando sus supuestos ontológicos, epistemológicos, metodológicos y axiológicos. Finalmente, presentamos un modelo conceptual de design science y su utilidad potencial para nuevas formas de producción científica y tecnológica, considerando los ciclos de relevancia, diseño y rigor, así como destacando la importancia del método design science (DSR) en la realización de investigaciones orientadas por el uso de los resultados. Tal perspectiva puede despertar nuevas reflexiones y debates en el campo académico sobre formas alternativas para el desarrollo y la evaluación de la investigación científica y tecnológica.

Palabras clave: Design science. CT\&I. Investigación académica. Universidad. Innovación. 


\section{INTRODUCTION}

In recent decades, the search for relevant research, capable of contributing to the scientific, technological and innovative development of society, has been part of a recurrent discourse of governments, scholars and the academia itself (GIBBONS, LIMOGES, NOWOTNY et al., 1994; VAN AKEN, 2004, 2005; HESSELS and LENTE, 2008; SCHWARTZMAN, 2008; EUROPEAN COMMISSION, 2010; BORNMANN, 2013; DRESCH, LACERDA and ANTUNES JUNIOR, 2015; MCNIE, PARRIS and SAREWITZ, 2016).

Part of this problem is due to the division between scholars, concerned with rigor, and practitioners, concerned with relevance (HODGKINSON, HERRIOT and ANDERSON, 2001; VAN AKEN, 2004). The consequence of this division has generated a fragmentation of academic research (ANDERSON, HERRIOT and HODGKINSON, 2001), contributing to the fact that dualities such as rigor and relevance, theory and practice, academia and society seem insurmountable barriers in traditional research models (AVENIER, 2010).

In the literature it is possible to identify some researches that tried to overcome these dualities through the following theoretical approaches: Finalization in Science (BÖHME, VAN DEN DAELE, HOHLFED et al., 1983); researches and strategic sciences (HESSELS and LENTE, 2008); post-normal science (FUNTOWICZ and RAVETZ, 1993; HESSELS and LENTE, 2008); mode 2 of knowledge production (GIBBONS, LIMOGES, NOWOTNY et al., 1994; HESSELS and LENTE, 2008; BORNMANN, 2013); innovation systems (HESSELS and LENTE, 2008); academic capitalism (SLAUGHTER and LESLIE, 1997; HESSELS and LENTE, 2008); triple helix model (ETZKOWITZ and LEYDESDORFF, 2000) and post-academic science (HESSELS and LENTE, 2008).

However, it is noticeable that such reflections have evolved little into practical results. According to Holmstrom, Ketokivi and Hameri (2009), ambitious efforts in various fields of study to make academic research more relevant remain undefined over decades, as the interests of academia do not seem to converge with the demands of society, which makes the need for new research approaches emerge.

The issue for much of the academic research is that researchers still believe that the mission of their studies should be oriented towards understanding the world as it is. Thus, many researchers are afraid of the kind of research that seeks to develop knowledge capable of improving the world by dealing with new forms of research on how the world could be (VAN AKEN, 2004, 2005; PANDZA and THORPE, 2010; DRESCH, LACERDA and ANTUNES JUNIOR, 2015).

According to Van Aken (2005), a large part of academic research, especially in the field of management, is of low relevance because it concentrates efforts on explaining, describing, exploring or predicting phenomena and their relationships, instead of proposing solutions to solve everyday problems. Thus, guiding studies by strategic demands, guided towards solutions, has become a great challenge for universities, especially the public ones, since society has demanded a more effective position on its actions (SCHWARTZMAN, 2008; MCTI, 2016).

In this context, Design Science positions itself as a useful alternative approach, able to guide academic research in the search for more relevant results, without disregarding the scientific rigor of academia (HEVNER, MARCH, PARK et al., 2004; VAN AKEN, 2004, 2005; MANSON, 2006; DRESCH, LACERDA and ANTUNES JUNIOR, 2015; BASKERVILLE, BAIYERE, GREGOR et al., 2018; DENG and JI, 2018; HEVNER, BROCKE and MAEDCHE, 2019). Such approach favors the construction of a type of transdisciplinary knowledge, contradicting the logic of academic productivity when seeking concrete solutions to the problems of society (GIBBONS, LIMOGES, NOWOTNY et al., 1994; ANDERSON, HERRIOT and HODGKINSON, 2001; HEVNER, MARCH, PARK et al., 2004; VAN AKEN, 2004, 2005; DRESCH, LACERDA and ANTUNES JUNIOR, 2015).

Therefore, the objective of this theoretical essay is to reflect on Design Science as an approach capable of contributing to an approximation of academic research with the activities of ST\&I, aligning the efforts of academia with the needs of society. Such perspective may facilitate the targeting of use oriented research or technologies (BALBACHEVSKY, 2008; AURANEN and NIEMINEN, 2010; EUROPEAN COMMISSION, 2010; HICKS, 2012; MUSCIO, QUAGLIONE and VALLANTI, 2013).

Even though some scholars consider Design Science a research paradigm, with distinct purposes, methods and nature (VAN AKEN, 2004; VAISHNAVI and KUECHLER, 2004; MANSON, 2006; AVENIER, 2010; DRESCH, LACERDA and ANTUNES JUNIOR, 2015; VAN AKEN CHANDRASEKARAN and HALMAN, 2016; DENG and JI, 2018; HEVNER, BROCKE and MAEDCHE, 2019; SYED, DHILLON and MERRICK, 2019), in this theoretical essay the term "research approach" will be adopted because it is understood that this is a field of study still under construction and unknown to most of academia (VAN AKEN, CHANDRASEKARAN and HALMAN, 2016; BASKERVILLE, BAIYERE, GREGOR et al., 2018), proving to be in need of further discussion and theoretical study. 


\section{EVALUATION OF ACADEMIC RESEARCH THROUGH ITS RELEVANCE}

Scientific and technological research has been increasingly recognized as an important activity for generating innovation and promoting sustainable economic and social development (HEINZE, SHAPIRA, ROGERS and SENKER, 2009; EUROPEAN COMMISSION, 2010; BORGES, 2016). In this context, academic research has been undergoing changes in recent decades, mainly due to the scarcity of resources and the notion that science must assume its share of responsibility in solving society's problems (AURANEN and NIEMINEN, 2010; EUROPEAN COMMISSION, 2010; HICKS, 2012).

A report by the European Commission highlighted that academic research performance should be considered an important factor in the development of countries, especially for the promotion of innovation (EUROPEAN COMMISSION, 2010). Traditionally, the evaluation of academic research has been based on the number of publications and citations. In response to the demands for a broader responsibility of universities, several countries now pay more attention to the results and benefits of research, especially in relation to its social, economic, cultural and environmental impacts (EUROPEAN COMMISSION, 2010).

Such changes have put pressure on universities and research institutions for more relevant and effective results (BALBACHEVSKY, 2008; AURANEN and NIEMINEN, 2010; EUROPEAN COMMISSION, 2010; HICKS, 2012; MUSCIO, QUAGLIONE and VALLANTI, 2013). Thus, it has been possible to identify new initiatives to evaluate academic research through the quality of its results in several countries: Germany, Finland, France, Netherlands, Italy, United Kingdom, Australia, among others (AURANEN and NIEMINEN, 2010; EUROPEAN COMMISSION, 2010; HICKS, 2012).

In summary, the initiatives presented demonstrate the need to reflect on new ways of planning and evaluating academic research, valuing the relevance and impacts of its results, both for scientific quality (publications and citations) and for cultural, economic and social contributions (AURANEN and NIEMINEN, 2010; EUROPEAN COMMISSION, 2010; HICKS, 2012).

In the Brazilian context, the University Reflection Forum (FÓRUM DE REFLEXÃO UNIVERSITÁRIA, 2002), created in 1999 by researchers from the State University of Campinas (UNICAMP), already warned about the need for changes in research planning and evaluation: they would turn to sustainable development and not divorced from reality, as illustrated in the following excerpt:

The relevance of investing public resources in scientific and technological research in any country, especially in developing countries such as Brazil, with notable social needs, must always be demonstrated with new and eloquent arguments. In these times, when the simple arithmetic of publications and quotations begins to decline, it is necessary to recover the humanist arguments that sustain the nobility of the constant search for knowledge and the pragmatists that indicate that research is the basis of innovation, essential to economic development and wealth generation (FÓRUM DE REFLEXÃO UNIVERSITÁRIA, 2002, p. 15).

The quoted excerpt already stressed the need for changes in the way of producing science in Brazil. In an optimistic hypothesis, Brazilian researchers would be, at last, gradually, moving away from a "[...] science, mostly reflexive in favor of a science with greater autonomy, relevance, local leadership and, above all, with consequent implications for the scientific, technological, social and cultural development of the State and the country" (FÓRUM DE REFLEXÃO UNIVERSITÁRIA, 2002, p. 16).

These discussions were also highlighted in the National Post-Graduate Plan (PNPG), proposed by the Coordination for the Improvement of Higher Level Personnel (CAPES), from 2005 to 2010. Among the challenges presented were the concern with the strategic induction in Brazilian research and the impact of graduate activities on the productive sector and society in general (BRASIL, 2010).

Thus, the incorporation of more innovative studies aimed at promoting socioeconomic development and the inclusion of social parameters in the evaluation processes have emerged as important demands with regard to the excellence of Brazilian research, especially in relation to academic investigations (BRASIL, 2010). 
Among various criticisms attributed to the Brazilian research system, an excessive appreciation of academic indicators, such as numbers of publications and citations, to the detriment of the social impact of research (SCHWARTZMAN, 2008) is noted. The current system stimulates a stereotyped behavior of researchers, who tend to adhere to routines recognized as efficient and legitimized by institutions or regulatory agencies to ensure access to the "valuable" performance indicators (BALBACHEVSKY, 2008).

Consequently, it is clear that the Brazilian model of scientific and technological production needs to evolve into planning models guided by the relevance of its results (SCHWARTZMAN, 2008; BRASIL, 2010). Despite not identifying a precise definition in the literature of what would be a relevant study, Lima and Wood Júnior (2014) define that there is a consensus that the notion of "relevance" of scientific research refers to three central steps: outputs, results and impacts.

The outputs would be the "products" of scientific and technological activity (artifacts), including publications, reports, patents, software, among others. The results would be represented by the research activities, and could be conceptual (a new theory), practical (a new technique) or physical (a new product). The impacts would be represented by contributions (benefits) generated and/or expected by the scientific community and/or society at large (EUROPEAN COMMISSION, 2010; LIMA and WOOD JUNIOR, 2014). This understanding is close to the concept adopted by Wood Junior, Costa, Lima and Guimarães (2016, p. 24), who considered the social impact of scientific research as:

[...] the benefit received by individuals or groups, by an organization (e.g., a private or public company, or a social organization), by a sector of activities (e.g., a production chain), by a scientific field (e.g., the field of organizational studies or the field of technology management), or by society in general, originated by processes related to the generation or dissemination of knowledge, and to teaching, carried out within the scope of teaching and research institutions.

It is about expanding traditional metrics, such as numbers of publications and quotations, to a research agenda guided by the explicit definition of society's problems, and also by possible solutions for the development and well-being of the population, either by incorporating innovation or by including social parameters in the evaluation of academic research (SCHWARTZMAN, 2008; BRASIL, 2010).

In this context, the Design Science has shown an interesting approach to the progress of science, for valuing the creation of technological artifacts and scientific knowledge relevant to social systems and organizations (HEVNER, MARCH, PARK et al., 2004; VAN AKEN, 2004, 2005; BASKERVILLE, KAUL and STOREY, 2015; DRESCH, LACERDA and ANTUNES JUNIOR, 2015; BASKERVILLE, BAIYERE, GREGOR et al., 2018; DENG and JI, 2018).

Even though studies on Design Science are not recent (MARCH and SMITH, 1995; SIMON, 1996; ROMME, 2003; VAN AKEN, 2004, 2005; MARCH and STOREY, 2008; AVENIER, 2010; HEVNER and ANDERSON, 2014; NIINILUOTO, 2014; DRESCH, LACERDA and ANTUNES JUNIOR, 2015; BASKERVILLE, BAIYERE, GREGOR et al., 2018), literature on the subject has little evolved over decades, gaining notoriety only since 2000, with publications in the areas of Economics and Business, Business Administration and Information Systems.

Furthermore, Van Aken, Chandrasekaran and Halman (2016), Baskerville, Baiyere, Gregor et al. (2018) and Deng and Ji (2018) highlight that the concepts and applications of Design Science still represent an unknown territory for many researchers, especially in the search for more relevant and problem-solving oriented studies. Thus, it is necessary to discuss the fundamentals of Design Science, comparing its assumptions with other research approaches.

\section{DESIGN SCIENCE FUNDAMENTALS}

The origin of Design Science can be attributed to the seminal work of the American economist and psychologist Herbert A. Simon, The sciences of the artificial, 1969 (VAN AKEN, 2004, 2005; MARCH and STOREY, 2008; AVENIER, 2010; HEVNER and ANDERSON, 2014; NIINILUOTO, 2014; DRESCH, LACERDA and ANTUNES JUNIOR, 2015; DENG and JI, 2018). In his work, Simon drew attention to the fact that the world is more artificial (manipulated by man) than natural. By giving value to artificial systems, such as products, technologies, organizations and issues of society, new reflections have emerged on the limitations 
of traditional sciences in generating knowledge capable of solving the day-to-day problems (SIMON, 1996; VAN AKEN, 2004; AVENIER, 2010; DRESCH, LACERDA and ANTUNES JUNIOR, 2015).

In terms of purpose, Design Science seeks to produce artifacts capable of satisfying a desired situation (HOLMSTRÖM, KETOKIVI and HAMERI, 2009), revealing itself as a pragmatic type of problem-solving research (ANDERSON, HERRIOT and HODGKINSON, 2001; DRESCH, LACERDA and ANTUNES JUNIOR, 2015). Despite the emphasis on practical utility, this type of research also values theoretical-methodological rigor as important for the foundation and evaluation of the investigations developed (HEVNER, MARCH, PARK et al., 2004; HEVNER, 2007; DRESCH, LACERDA and ANTUNES JUNIOR, 2015; BASKERVILLE, BAIYERE, GREGOR et al., 2018).

Regarding the nature of objects, Design Science understands social and organizational issues as artificial, with poorly defined descriptive and imperative properties. The research takes into account that each situation is unique and based on purposes, satisfactory solutions, systemic thinking and limited information, in addition to emphasizing participation and discourse as a means of intervention (ROMME, 2003).

In comparing Design Science with paradigms of the explanatory sciences, such as positivism and interpretivism, it is possible to notice some ontological, epistemological, methodological and axiological differences, as presented in Box 1.

Box 1

Positivism, interpretivism and Design Science

\begin{tabular}{|c|c|c|c|}
\cline { 2 - 4 } \multicolumn{1}{c|}{} & \multicolumn{1}{c|}{ Positivism } & Interpretivism & Design Science \\
\hline Ontology & $\begin{array}{c}\text { A single recognizable } \\
\text { and probabilistic reality, } \\
\text { regardless of the researcher. }\end{array}$ & $\begin{array}{c}\text { Multiple socially constructed } \\
\text { realities. Reality and individual } \\
\text { cannot be separated. }\end{array}$ & $\begin{array}{c}\text { Multiple realities, contextually } \\
\text { located in alternative states of } \\
\text { the world through the interaction } \\
\text { between technology and society. }\end{array}$ \\
\hline Epistemology & $\begin{array}{c}\text { Objective. The observer } \\
\text { assumes an impartial attitude } \\
\text { of truth. }\end{array}$ & $\begin{array}{c}\text { Subjective. Knowledge is } \\
\text { generated through social } \\
\text { construction of the world based } \\
\text { on experiences, values and } \\
\text { objectives of researchers. }\end{array}$ & $\begin{array}{c}\text { Knowledge emerges from } \\
\text { human action, built within a } \\
\text { specific context in which iterative } \\
\text { definitions reveal meanings. }\end{array}$ \\
\hline Methodology & $\begin{array}{c}\text { Observational, quantitative } \\
\text { and statistical. }\end{array}$ & $\begin{array}{c}\text { Participative, qualitative. } \\
\text { Hermeneutic and dialectic. }\end{array}$ & $\begin{array}{c}\text { Mixed research methods to } \\
\text { measure the impact of artifacts } \\
\text { on the system as a whole. }\end{array}$ \\
\hline Axiology & $\begin{array}{c}\text { Universal and beautiful truth; } \\
\text { prediction. }\end{array}$ & $\begin{array}{c}\text { Understanding is descriptive and } \\
\text { situated in context. }\end{array}$ & $\begin{array}{c}\text { Control; creation; improvement; } \\
\text { understanding. }\end{array}$ \\
\hline
\end{tabular}

Source: Adapted from Vaishnavi and Kuechler (2004) and Manson (2006).

The ontological vision of Design Science recognizes the possibility of changing states of the world through the introduction of new artifacts. Thus, this approach assumes multiple world realities, in which the focus is no longer on natural laws or individual perceptions, but on the states of change generated by the interaction between new technologies and the social world (VAISHNAVI and KUECHLER, 2004; MANSON, 2006).

The epistemological view holds that knowledge is generated through human action. The researcher investigates facts (problems) and understands what they mean through iterative processes of meaning construction. Based on meanings, an artifact is built to solve problems in specific contexts, considering its functionality and relevance (VAISHNAVI and KUECHLER, 2004; MANSON, 2006).

The methodology used in Design Science oriented research tends to be dualistic in nature. During the design and construction phase of the research, the methodology can be characterized as a creative process, as it involves the generation of new thoughts and imaginative leaps into future possibilities (MANSON, 2006). Already in the evaluation phase, several methods can be used to measure the effectiveness of the proposed artifact (MANSON, 2006). Therefore, the use of mixed methods is accepted. 
Moreover, in axiological terms, the researcher based on the Design Science approach values truth and understanding, but goes beyond these by influencing and controlling the environment. The relevance of research is also emphasized, as a successful research project seeks to value new practices or functionalities of certain knowledge to provide new discoveries to the investigated research fields (VAN AKEN, 2004; VAISHNAVI and KUECHLER, 2004; MANSON, 2006).

Unlike positivism and interpretivism, research based on Design Science can meet the interests of academics (rigor) and practitioners (relevance) in investigations in which the processes of conception and evaluation of products, theories, technologies or other formats of artifacts are oriented to solving real-world problems (MARCH and SMITH, 1995; SIMON, 1996; VAN AKEN, 2005; BASKERVILLE, KAUL and STOREY, 2015; DRESCH, LACERDA and ANTUNES JUNIOR, 2015).

While explanatory science-oriented research is concerned with describing problems about "how things are", Design Scienceoriented research goes beyond proposing (heuristic) solutions about "how things could be" in order to achieve goals and solve day-to-day problems (SIMON, 1996; VAN AKEN, 2004, 2005; PANDZA and THORPE, 2010; NIINILUOTO, 2014; DRESCH, LACERDA and ANTUNES JUNIOR, 2015; VAN AKEN and CHANDRASEKARAN; HALMAN, 2016; DENG and JI, 2018; BASKERVILLE, BAIYERE, GREGOR et al., 2018).

There is also the fact that explanatory science-oriented research seeks to understand situations or events that have already occurred, while Design Science-oriented research endeavors to investigate and alter future events (VAN AKEN, 2004, 2005). The researcher moves from a position of observer of reality to one of protagonist by proposing solutions to a class of problems (VAN AKEN, 2004).

However, despite the differences presented, Van Aken (2004) states that the progress of Design Science is based on an effective partnership between explanatory sciences and design sciences, which contributes to the development of tried and tested technological rules. A researcher can design an airplane wing based on tests and heuristic rules (Design Science). However, such action can be more efficient when guided by laws and knowledge of aerodynamics and mechanics (explanatory sciences).

Thus, although comparisons between Design Science and other research approaches are important, several authors highlight that there is no opposition, but rather complementarity, because only with the combination of these approaches will it be possible to advance in several areas of knowledge (HEVNER, MARCH, PARK et al., 2004; VAN AKEN, 2004; HOLMSTRÖM, KETOKIVI and HAMERI, 2009; AVENIER, 2010; DRESCH, LACERDA and ANTUNES JUNIOR, 2015; VAN AKEN, CHANDRASEKARAN and HALMAN, 2016).

\section{ACADEMIC RESEARCH AND PROGRESS IN ST\&I: A DESIGN SCIENCE APPROACH}

Based on the concepts presented, several researchers point out that a greater adoption of Design Science in academic research could improve the quality of its results, both in scientific production and in the generation of innovations (VAN AKEN, 2004, 2005; HOLMSTRÖM, KETOKIVI and HAMERI, 2009; CRONHOLM, GÖBEL, LIND et al., 2013; HEVNER and ANDERSON, 2014; DRESCH, LACERDA and ANTUNES JUNIOR, 2015; BASKERVILLE, BAIYERE, GREGOR et al., 2018; HEVNER, BROCKE and MAEDCHE, 2019; SYED, DHILLON and MERRICK, 2019).

Verkerke, Houwen, Broekhuis et al. (2013) state that science and design have always been separate areas for specific purposes. While science analyzes the existing world to create new knowledge, design uses the existing knowledge to create a new world. However, these perspectives can converge to a broader view of problems in reality. Design can benefit from scientific methods, resulting in more effective planning processes and better products. Science can benefit from a design approach, resulting in more relevant scientific results (VERKERKE, HOUWEN, BROEKHUIS et al., 2013).

Thus, science and design are important because theoretical objectives allow to conduct descriptive research, while pragmatics allow to conduct prescriptive and change-oriented research (BASKERVILLE, KAUL and STOREY, 2015). By considering design and science as complementary and essential requirements, such approach favors the construction of a type of transdisciplinary knowledge, aimed at relevance and rigor (VAN AKEN, 2004, 2005; ANDERSON, HERRIOT and HODGKINSON, 2001). 
Considering the limitations and critics to academic research in promoting scientific and technological progress (BALBACHEVSKY, 2008; AURANEN and NIEMINEN, 2010; EUROPEAN COMMISSION, 2010; HICKS, 2012; MUSCIO, QUAGLIONE and VALLANTI, 2013; BORGES, 2016; MCTI, 2016), Design Science presents itself as a viable alternative to bring academic research closer to ST\&I actions, especially in countries with low technological capacity such as Brazil (DRESCH, LACERDA and ANTUNES JUNIOR, 2015).

Cronholm, Göbel, Lind et al. (2013) highlight that academia is a potential environment for Design Science oriented research development, mainly by bringing research groups closer to other organizations in generating innovations and by supporting the planning and direction of future investigations.

Baskerville, Baiyere, Gregor et al. (2018, p. 368) point out: "[...] as theories can be practical, design artifacts can also incorporate theory". Such characteristics can overcome the science-technology dualism in interactive cycles of scientific and technological construction, considering their contributions to the evolution of both. Thus, their contributions lie in the possibility of introducing already existing scientific knowledge in the proposition of artifacts in new application contexts. Moreover, they allow the addition of prescriptive contributions of artifacts to extend and generalize new scientific contributions (BASKERVILLE, BAIYERE, GREGOR et al., 2018).

To facilitate the characterization of Design Science oriented research, Hevner, March, Park et al. (2004) highlighted seven main guidelines: (i) design as an artifact; (ii) relevance of the problem; (iii) research contribution; (iv) scientific rigor; (v) design as a process; (vi) project evaluation; and (vii) research communication. These guidelines, when applied in the planning of academic research, could make the results more rigorous and relevant, favoring the advancement of actions in the National System of Science, Technology and Innovation (SNCTI).

The first guideline takes into account that a Design Science oriented research must develop an innovative artifact (HEVNER, MARCH, PARK et al., 2004). The development of an artifact through constructs, models, methods, instantiations, among other forms, allows researchers to solve organizational problems, improve social structures, develop new technologies or improve theories (MARCH and SMITH, 1995; SIMON, 1996; HEVNER, MARCH, PARK et al., 2004; DRESCH, LACERDA and ANTUNES JUNIOR, 2015).

However, the development of the artifact must always be associated with a relevant problem (second guideline) as well as its possible contributions (third guideline). The concern with the relevance and contributions of researches represent, thus, important guidelines of Design Science for academic researches and for the promotion of progress in SNCTI (HEVNER, MARCH, PARK et al., 2004; VAN AKEN, 2004, 2005; HOLMSTRÖM, KETOKIVI and HAMERI, 2009; CRONHOLM, GÖBEL, LIND et al., 2013; DRESCH, LACERDA and ANTUNES JUNIOR, 2015).

Design Science oriented research should also value the theoretical-methodological rigor (fourth guideline) by which it will be conducted. Rigor guarantees the production of knowledge legitimated by the scientific community, allowing the results to be extended to other similar contexts (HEVNER, MARCH, PARK et al., 2004; VAN AKEN, 2004, 2005; DRESCH, LACERDA and ANTUNES JUNIOR, 2015).

According to Hevner, March, Park et al. (2004), the process of constructing the artifact is inherently iterative, so design activities should occur throughout the research process (fifth guideline). Unlike other approaches, what is sought is not the optimal solution for a given problem, but the most effective solution. In this context, creativity and heuristic strategies prove to be necessary skills throughout the research.

Different representations of a problem can provide varied techniques to measure how good a solution is (HEVNER, MARCH, PARK et al., 2004) - which would be useful to academic research by allowing new processes of abstraction and reflection on satisfactory solutions for a given problem, allowing theoretical and/or methodological advances.

Once the artifacts capable of generating satisfactory solutions are identified, the evaluation of the research (sixth guideline) becomes evident as an essential process (HEVNER, MARCH, PARK et al., 2004; HEVNER, 2007). This evaluation guideline can be of great value to rigorously demonstrate the usefulness, quality and effectiveness of an artifact. The evaluation provides the essential feedback for the development of the artifact, from the planning step to the research completion step (HEVNER, MARCH, PARK et al., 2004; MANSON, 2006). 
Finally, research results must be effectively communicated (seventh guideline) to various target audiences (HEVNER, MARCH, PARK et al., 2004). This allows researchers to legitimize the knowledge generated, as well as society to benefit from the results, since they derive from some problem and/or demand of society (HEVNER, MARCH, PARK et al., 2004; GREGORY, 2015).

In addition, Design Science-oriented research involves the interaction of three main cycles: (i) relevance; (ii) rigor and (iii) design (HEVNER, MARCH, PARK et al., 2004; HEVNER, 2007). The cycle of relevance concerns the demands of society in terms of social systems, organizations and technologies. The cycle of rigor can be represented by existing knowledge and by the proposition of new technological rules. Finally, the design cycle refers to the processes of solutions to the demands, either through new theories or artifacts (HEVNER, MARCH, PARK et al., 2004; HEVNER, 2007; DRESCH, LACERDA and ANTUNES JUNIOR, 2015).

Therefore, considering the guidelines and cycles discussed by Hevner, March, Park et al. (2004) and Hevner (2007), as well as their potential benefits, a model for Design Science oriented research is proposed, as presented in Figure 1.

Figure 1

Model for Design Science oriented research

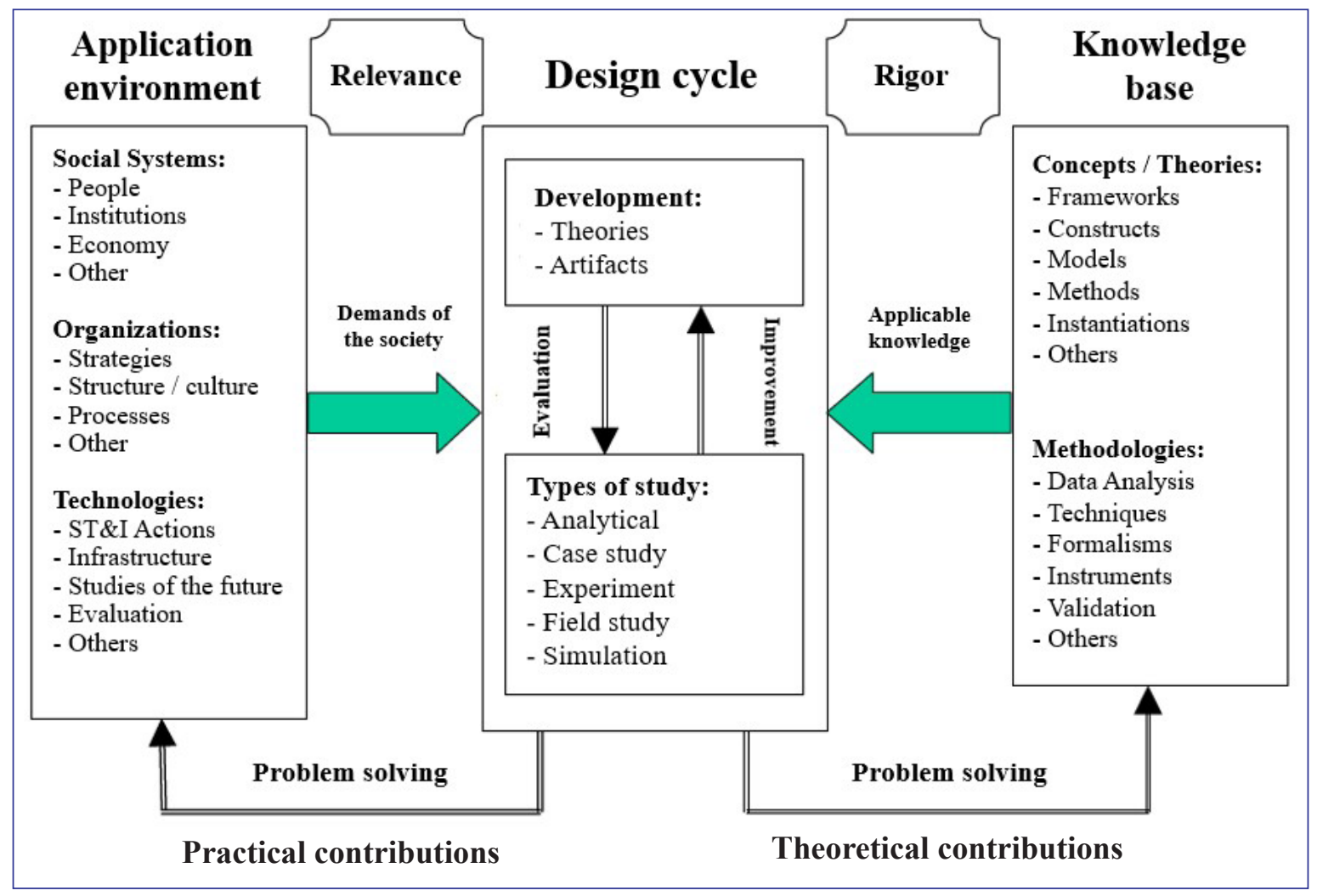

Source: Adapted from Hevner, March, Park et al. (2004).

The model represents the conceptual framework for understanding, executing and evaluating Design Science oriented research. On the one hand, the model addresses steps in the explanatory sciences, seeking to describe, explain or predict phenomena. On the other hand, it approaches steps of the design sciences, seeking to meet the demands through the development of theories or artifacts oriented to problem solving (HEVNER, MARCH, PARK et al., 2004; VAN AKEN, 2004; HEVNER, 2007; BASKERVILLE, KAUL and STOREY, 2015).

The application environment guides the research problem (cycle of relevance) and may involve: (i) social systems related to people, institutions, economic issues, among others; (ii) companies (businesses), regarding strategies, structures and organizational culture, new processes, among others; and (iii) technologies, with strengthening of ST\&l actions, issues 
related to infrastructure, strategic studies, evaluation processes, among others. These application environments allow for the development of more relevant research, guided by the use of its results.

Hevner, March, Park et al. (2004) point out that good research usually begins by identifying opportunities and/or problems in specific environments. In this context, it is considered that, regardless of the specificities of the research groups and researchers involved, the planning model, for the generation of the most relevant results, may be guided by several future demands or needs, whether of scientific, social or economic nature.

This planning step refers to the awareness process, responsible for identifying demands to start the investigation (VAISHNAVI and KUECHLER, 2004; MANSON, 2006). The model can support researchers in identifying broader demands of society. From this perspective, an engineering research group could, for example, guide its studies by industry demands. On the other hand, a Human Sciences research group could guide its studies by social demands or propose studies capable of solving gaps in scientific knowledge, contemplating different interests and fields of action.

The identification of society's demands would represent the cycle of relevance proposed in the conceptual model. As presented by Hevner, March, Park et al. (2004) and Hevner (2007), the cycle of relevance favors the identification of problems or research opportunities, aligning society's demands with research efforts. Thus, research could be directed to demands from social systems, organizations, technologies, among other application environments or interests of researchers and/or research groups.

Once relevant demands are identified, the design cycle begins by planning and evaluating artifacts capable of presenting solutions to the problems defined in the relevant cycle. By considering the design cycle through construction and evaluation of "artifacts", new possibilities open up, as research can be planned to generate new constructs, models, methods, instantiations or theoretical contributions (MARCH and SMITH, 1995; SIMON, 1996; VAN AKEN, 2005; DRESCH, LACERDA and ANTUNES JUNIOR, 2015).

From this perspective, the product of a research can be translated into three types of contribution: (i) of a scientific nature, such as progress in gaps in scientific knowledge; (ii) of an economic nature, such as the generation of patents and solutions for the productive sector; and (iii) of a social nature, through public policies, social innovations, among other actions capable of improving the population's quality of life.

The design cycle refers to a central step, since it represents the process of knowledge construction in the form of artifacts capable of generating solutions to different kinds of scientific, economic or social contributions, favoring the design of research and its processes or steps (HEVNER, MARCH, PARK et al., 2004; MANSON, 2006; HEVNER, 2007; DRESCH, LACERDA and ANTUNES JUNIOR, 2015).

In this step, the use of already existing knowledge such as laws, theories, methods and/or technologies capable of explaining or predicting the investigated phenomena is necessary. The use of this knowledge guarantees the theoretical/methodological rigor of the research, allowing the improvement and/or evaluation of new scientific contributions.

The identification of previous knowledge (state of the art and technique) would represent the cycle of rigor, responsible for identifying appropriate theories, methods and technologies for the construction, foundation and evaluation of the artifact (HEVNER, MARCH, PARK et al., 2004; HEVNER, 2007; DRESCH, LACERDA and ANTUNES JUNIOR, 2015). The cycle of rigor guarantees the production of scientific and/or technological knowledge through processes legitimized by academia, allowing the extension of results in similar contexts (HEVNER, MARCH, PARK et al., 2004; HEVNER, 2007; VAN AKEN, 2004, 2005; DRESCH, LACERDA and ANTUNES JUNIOR, 2015).

Hevner and Anderson (2014), as well as Baskerville, Baiyere, Gregor et al. (2018), highlight that Design Science has a clear potential to improve current practices of scientific and technological evolution, since it provides a unifying language and a set of concepts that allow creative solutions in strategic application domains in society.

The focus is no longer on understanding natural laws or social systems, but on building artifacts to solve society's problems (HEVNER, MARCH, PARK et al., 2004; VAN AKEN, 2005; DRESCH, LACERDA and ANTUNES JUNIOR, 2015; DENG and JI, 2018; BASKERVILLE, BAIYERE, GREGOR et al., 2018; HEVNER, BROCKE and MAEDCHE, 2019).

To facilitate the development of Design Science oriented research, the use of the Design Science Research (DSR) method becomes fundamental. It is structured by processes of planning, analysis, reflection and abstraction (MARCH and SMITH, 1995; VAISHNAVI and KUECHLER, 2004; DRESCH, LACERDA and MIGUEL, 2015). 
According to Manson (2006), the DSR method is composed of two essential steps: (i) construction of the artifact and (ii) evaluation. The artifact construction step involves creative processes of awareness about certain problems/demands and possible suggestions to solve them. The evaluation step involves testing processes on the utility and relevance of the proposed artifact, as shown in Figure 2.

Figure 2

Steps of the DSR method

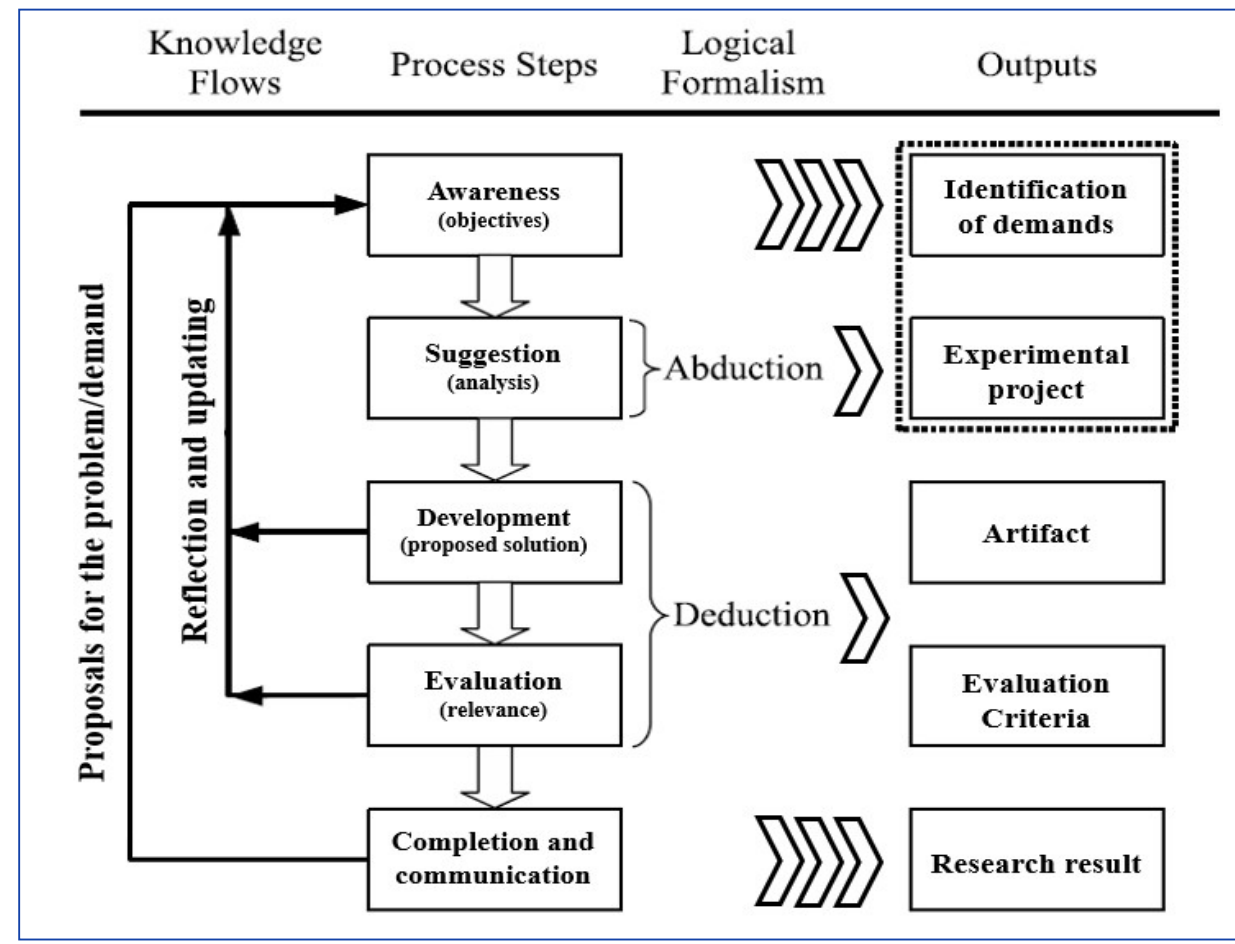

Source: Adapted from Manson (2006, p. 163).

The DSR method can be understood as a concrete alternative for conducting scientific and technological research, constituting an approach of scientific rigour, capable of placing university intelligence at the service of the enormous strategic challenges. In addition to exploring, describing or explaining a given phenomenon, the DSR method allows for designing solutions (DRESCH, LACERDA and MIGUEL, 2015).

The research process begins when the researcher becomes aware of a certain problem and/or demand (cycle of relevance). The awareness of the researcher may arise from social demands, industry, government, an emerging technology, among others. The result of this step should be the construction of a formal or informal proposal to start an investigation (VAISHNAVI and KUECHLER, 2004; MANSON, 2006).

Once a relevant demand has been identified, the researcher must analyze the possible suggestions to solve the proposed problem, giving rise to the suggestion step (design cycle). In this step the researcher needs to focus on the real problem, keeping attention on the possible variables capable of interfering in the development of theories or artifacts, such as: people, organizations, technologies and existing knowledge (HEVNER, MARCH, PARK et al., 2004; MANSON, 2006; BECK, WEBER and GREGORY, 2013).

The process of proposing solutions for an experimental project must be essentially creative; thus, the abductive method manifests the ideal logical formalism at this step of research (MANSON, 2006). The abdutive method "[...] consists in studying facts and proposing a theory to explain them. Therefore, abduction is a process of creating explanatory hypotheses for a given phenomenon and/or situation" (DRESCH, LACERDA and ANTUNES JUNIOR, 2015, p. 62).

Unlike inductive and hypothetical-deductive methods, Haig (2005) stresses that the abductive method values problem solving as an essential part of its characterization. Once the possible solutions are analyzed, the research development step is taken. In 
this step, the researcher will build one or more artifacts to solve a certain theoretical and/or practical problem, which should be evaluated through previously defined criteria (VAISHNAVI and KUECHLER, 2004; MANSON, 2006).

It is sought to build heuristics that allow generalizations in similar contexts. Deviations from the expected behavior of the artifact force researchers to generate new suggestions and new cycles of reflection and updating (VAISHNAVI and KUECHLER, 2004; HAIG, 2005; MANSON, 2006; DRESCH, LACERDA and ANTUNES JUNIOR, 2015).

In the development and evaluation steps (cycle of rigor), the deductive method allows the use of existing knowledge and theories to propose elements that may explain or predict certain phenomena. The deductive method is characterized by the use of logic in the construction of knowledge. By knowing laws or theories and using them in a deductive way, the researcher can build new knowledge to explain or predict the behavior of the proposed artifact (DRESCH, LACERDA and ANTUNES JUNIOR, 2015).

As Vaishnavi and Kuechler (2004) and Manson (2006) state, the DSR method takes into account constructivist approaches (at the beginning of the process) and reflective approaches (during the process) for understanding and changing reality. After these steps, researchers record the behavior of the artifact and compare it with predictions identified by means of abductive methods. These observations are interpreted and serve as the basis for new discoveries.

As for the completion step, it consists in the formalization of the whole process of knowledge construction and its communication with the public of interest (VAISHNAVI and KUECHLER, 2004; MANSON, 2006; DRESCH, LACERDA and ANTUNES JUNIOR, 2015). This step represents the consolidation of research results through scientific studies (thesis, articles, etc.) to be disseminated in specific scientific communities.

In this context, it is perceived that Design Science represents an alternative approach for the promotion of progress in ST\&I, by contributing to the following challenges: (i) to reduce the gap between theoretical development and its practical repercussions; (ii) to bring academia closer to other non-academic institutions; (iii) to promote scientific and technological development; and (iv) to generate solutions to society's problems (BASKERVILLE, KAUL and STOREY, 2015; DRESCH, LACERDA and ANTUNES JUNIOR, 2015).

\section{FINAL CONSIDERATIONS}

Even though important, explanatory, descriptive and/or explorative research approaches may result in scientific productions that are distant from a real context, inherently composed of complexities that generate demands for solutions to related issues. Aiming to reflect on an alternative and complementary approach, capable of contributing to an approximation of academic research with ST\&I activities, this theoretical essay highlighted the potential of Design Science in the development of more pragmatic and strategic studies.

To this end and aiming to expand the understanding of concepts, a conceptual model was presented for the understanding, execution and evaluation of Design Science oriented research. In addition, the importance of the DSR method in conducting these investigations was emphasized, considering the steps of construction and evaluation of technological artifacts and scientific knowledge.

The concepts presented are capable of contributing to an approximation of academic research with the activities of ST\&I, since they align the scientific rigor, necessary for the generation of knowledge in academia, with the relevance of studies in the face of the demands of society, involving relationships with social systems, companies (business) and technologies.

The theoretical and methodological aspects presented in this theoretical essay demonstrate that Design Science represents an important research approach oriented to academic rigor and relevance, and can contribute to the development of ST\&I based on the following results: (i) reduce the gap between theoretical development and its practical repercussions; (ii) bring the academic environment closer to non-academic organizations; (iii) develop or enhance knowledge capable of promoting scientific and technological development; (iv) generate solutions to problems identified in certain contexts; (v) improve current innovation practices; (vi) develop a language and a set of common concepts oriented to creativity; (vii) stimulate processes of abstraction and reflection on satisfactory solutions; and (viii) support the planning of strategic research for the scientific, technological and innovative development of the country. 
Such an approach can favour the development of research capable of generating three types of impact: (i) intellectual, aimed at generating creative ideas and scientific progress; (ii) economic, focused on technological advances capable of generating jobs and increasing the country's competitiveness; and (iii) social, related to the production of research capable of influencing public policies, reducing social inequalities and increasing the involvement of science in solving society's problems. Thus, Design Science is a relevant research approach for researchers, research groups, universities and development agencies, allowing the identification of strategic research topics capable of generating more relevant benefits to society.

Despite the potential of Design Science highlighted in this theoretical essay, what is proposed is not an abandonment or rupture in the way of doing research through other approaches, but rather to highlight the potential of Design Science in the development of more pragmatic and strategic studies for scientific and technological development.

It should be noted that it was not the objective of the study to point out relationships between the policies of ST\&I and the Design Science approach, nor to discuss the possible limitations of the application of this approach in the Brazilian context. However, an advance in the discussions may be directed to analyses in this regard. In addition, an agenda of future studies, especially empirical ones, on the challenges of using the premises of the Design Science approach in the academic environment, as well as the advantages and disadvantages of this approach in relation to other research approaches, is valid and necessary.

\section{ACKNOWLEDGEMENTS}

The authors thank the Federal Institute of Education, Science and Technology of South of Minas Gerais - IFSULDEMINAS, the Federal University of Lavras and the National Council for Scientific and Technological Development (CNPq) for their support in conducting and disseminating the research. 


\section{REFERENCES}

ANDERSON, N.; HERRIOT, P; HODGKINSON, G. P. The practitionerresearcher divide in Industrial, Work and Organizational (IWO) psychology: Where are we now, and where do we go from here? Journal of Occupational and Organizational Psychology, v. 74, n. 4, p. 391-411, 2001.

AURANEN, O.; NIEMINEN, M. University research funding and publication performance: An international comparison. Research Policy, v. 39, n. 6, p. 822-834, 2010.

AVENIER, M. Shaping a constructivist view of organizational Design Science. Organization studies, v. 31, n. 9-10, p. 1229-1255, 2010.

BALBACHEVSKY, E. Incentives and obstacles to academic entrepreneurship. In: SCHWARTZMAN, S. (Org.). University and Development in Latin America: Successful Experiences of Research Centers. Rio de Janeiro: Sense Publishers, 2008. p. 23-42.

BASKERVILLE, R. et al. Design science research contributions: finding a balance between artifact and theory. Journal of the Association for Information Systems, v. 19, n. 5, p. 358-376, 2018.

BASKERVILLE, R. L.; KAUL, M.; STOREY, V. C. Genres of inquiry in design-science research: Justification and evaluation of knowledge production. Mis Quarterly, v. 39, n. 3, p. 541-564, 2015.

BECK, R.; WEBER, S.; GREGORY, R. W. Theory-generating Design Science research. Information Systems Frontiers, v. 15, n. 4, p. 637-651, 2013.

BÖHME, G. et al. Finalization in Science: The Social Orientation of Scientific Progress. Dordrecht: D. Reidel Publishing Company, 1983.

BORGES, M. N. Ciência, tecnologia e inovação para o desenvolvimento do Brasil. Scientia Plena, v. 12, n. 8, p. 1-11, 2016.

BORNMANN, L. What is societal impact of research and how can it be assessed? A literature survey. Journal of the American Society for Information Science and Technology, v. 64, n. 2, p. 217-233, 2013.

BRASIL. Ministério da Educação. Coordenação de Aperfeiçoamento de Pessoal de Nível Superior. Plano Nacional de Pós-Graduação (PNPG) - 2011-2020. Brasília, DF: CAPES, 2010. Available at: <www. capes.gov.br/images/stories/download/Livros-PNPG-Volume-I-Mont. pdf>. Accessed on: Oct. 18, 2017.

CRONHOLM, S. et al. The need for systems development capability in Design Science research: enabling researcher-systems developer collaboration. Information Systems and e-Business Management, v. 11, n. 3, p. 335-355, 2013.

DENG, Q.; JI, S. A review of design science research in information systems: concept, process, outcome, and evaluation. Pacific Asia Journal of the Association for Information Systems, v. 10, n. 1, p. 1-36, 2018.

DRESCH, A.; LACERDA, D. P.; ANTUNES JUNIOR, J. A. V. Design Science research: Método de pesquisa para o avanço da ciência e tecnologia. Porto Alegre: Bookman, 2015.

DRESCH, A.; LACERDA, D. P.; MIGUEL, P. A. C. A Distinctive Analysis of Case Study, Action Research and Design Science Research. RBGN, v. 17, n. 56, p. 1116-1133, 2015.

ETZKOWITZ, H.; LEYDESDORFF, L. The dynamics of innovation: from National Systems and "Mode 2" to a Triple Helix of university-industrygovernment relations. Research policy, v. 29, n. 2, p. 109-123, 2000.
EUROPEAN COMMISSION. Assessing Europe's University-Based Research: Expert Group on Assessment of University-Based Research. Science in Society 2008 Capacities. Brussels: European Commission, 2010 .

FÓRUM DE REFLEXÃO UNIVERSITÁRIA - UNICAMP. Desafios da pesquisa no Brasil: uma contribuição ao debate. São Paulo em Perspectiva, v. 16, n. 4, p. 15-23, 2002.

FUNTOWICZ, S. O.; RAVETZ, J. R., Science for the post-normal age. Futures, v. 25, n.7, p. 739-755, 1993.

GIBBONS, M. et al. The new production of knowledge: The dynamics of science and research in contemporary societies. London: Sage, 1994.

GREGORY, J. Science Communication. In: WRIGHT, J. D. (Ed.). International Encyclopedia of the Social \& Behavioral Sciences. 2. ed. Orlando: Elsevier, 2015. p. 219-224.

HAIG, B. D. An abductive theory of scientific method. Psychological Methods, v. 10, n. 4, p. 371-388, 2005.

HEINZE, T. et al. Organizational and institutional influences on creativity in scientific research. Research Policy, v. 38, n. 4, p. 610-623, 2009.

HESSELS, L. K.; VAN LENTE, H. Re-thinking new knowledge production: a literature review and a research agenda. Research policy, v. 37, n. 4, p. 740-760, 2008.

HEVNER, A. R. A three-cycle view of design science research. Scandinavian Journal of Information Systems, v. 19, n. 2, p. 4, 2007.

HEVNER, A. R.; ANDERSON, J. Design Science and Innovation Practices: A Delphi Study. In: HELFERT, M.; DONNELLAN, B.; KENNEALLY, J. (Eds.). Design Science: Perspectives from Europe. European Design Science Symposium. Dublin: Springer International Publishing, 2014. p. 21-27.

HEVNER, A. R.; BROCKE, J. V.; MAEDCHE, A. Roles of digital innovation in design science research. Business \& Information Systems Engineering, v. 61 , n. 1, p. 3-8, 2019.

HEVNER, A. R. et al. Design science in information systems research. MIS quarterly, v. 28, n. 1, p. 75-105, 2004.

HICKS, D. Performance-based university research funding systems. Research Policy, v. 41, n. 2, p. 251-261, 2012.

HODGKINSON, G. P.; HERRIOT, P.; ANDERSON, N. Re-aligning the stakeholders in management research: lessons from industrial, work and organizational psychology. British Journal of Management, v. 12, Special Issue, p. S41-S48, 2001.

HOLMSTRÖM, J.; KETOKIVI, M.; HAMERI, A. Bridging practice and theory: a Design Science approach. Decision Sciences, v. 40, n. 1, p. 65-87, 2009.

LIMA, G. M. R.; WOOD JUNIOR, T. The social impact of research in business and public administration. Revista de Administração de Empresas, São Paulo, v. 54, n. 4, p. 458-463, 2014.

MANSON, N. J. Is operations research really research? ORiON: The Journal of ORSSA, v. 22, n. 2, p. 155-180, 2006.

MARCH, S. T.; SMITH, G. F. Design and natural science research on information technology. Decision Support Systems, v. 15, n. 4, p. 251-266, 1995. 
MARCH, S. T.; STOREY, V. C. Design science in the information systems discipline: an introduction to the special issue on design science research. MIS Quarterly, v. 32, n. 4, p. 725-730, 2008.

MCNIE, E. C.; PARRIS, A.; SAREWITZ, D. Improving the public value of science: a typology to inform discussion, design and implementation of research. Research Policy, v. 45, n. 4, p. 884-895, 2016.

MINISTÉRIO DA CIÊNCIA, TECNOLOGIA E INOVAÇÃO-MCTI. Estratégia Nacional de Ciência, Tecnologia e Inovação 2016 - 2019. Brasília: Ministério da Ciência, Tecnologia e Inovação, 2012. Available at: <www.mcti.gov.br>. Accessed on: Sept. 08, 2018.

MUSCIO, A.; QUAGLIONE, D.; VALLANTI, G. Does government funding complement or substitute private research funding to universities? Research Policy, v. 42, n. 1, p. 63-75, 2013.

NIINILUOTO, I. Values in Design Sciences. Studies in History and Philosophy of Science Part A, v. 46, p. 11-15, 2014.

PANDZA, K.; THORPE, R. Management as design, but what kind of design? An appraisal of the Design Science analogy for management. British Journal of Management, v. 21, n. 1, p. 171-186, 2010.

ROMME, A. G. L. Making a difference: Organization as design. Organization science, v. 14, n. 5, p. 558-573, 2003.

SCHWARTZMAN, S. (Org.). University and Development in Latin America: Successful Experiences of Research Centers. Rio de Janeiro: Sense Publishers, 2008.

SIMON, H. A. The sciences of the artificial. 3. ed. Cambridge: MIT press, 1996.
SLAUGHTER, S.; LESLIE, L. L. Academic capitalism: Politics, policies, and the entrepreneurial university. Baltimore: Johns Hopkins University Press, 1997.

SYED, R.; DHILLON, G.; MERRICK, J. The Identity Management Value Model: A Design Science Approach to Assess Value Gaps on Social Media. Decision Sciences, v. 50, n. 3, p. 498-536, 2019.

VAISHNAVI, V.; KUECHLER, W. Design Science Research in Information Systems. Association for Information Systems, 2004. Available at: <http://desrist.org/design-research-in-information-systems/>. Accessed on: Dec. 06, 2018.

VAN AKEN, J. E. Management research as a Design Science: articulating the research products of mode 2 knowledge production in management. British Journal of Management, v. 16, n. 1, p. 19-36, 2005.

VAN AKEN, J. E. Management research based on the paradigm of the Design Sciences: the quest for field-tested and grounded technological rules. Journal of Management Studies, v. 41, n. 2, p. 219-246, 2004.

VAN AKEN, J. E.; CHANDRASEKARAN, A.; HALMAN, J. Conducting and publishing design science research: Inaugural essay of the design science department of the Journal of Operations Management. Journal of Operations Management, 2016.

VERKERKE, G. J. et al. Science versus design; comparable, contrastive or conducive? Journal of the Mechanical Behavior of Biomedical Materials, v. 21, p. 195-201, 2013.

WOOD JUNIOR., T. et al. Impacto social: estudo sobre programas brasileiros selecionados de pós-graduação em Administração de Empresas. Revista de Administração Contemporânea, v. 20, n. 1, p. 21, 2016.

Donizeti Leandro de Souza

ORCID: https://orcid.org/ 0000-0002-4555-394X

Ph.D. in Business Administration at Federal University of Lavras; Professor and researcher at Federal Institute of Education, Science and Technology of South of Minas Gerais, Pouso Alegre - MG, Brazil. E-mail: donizeti.souza@ifsuldeminas.edu.br

Thais Assis de Souza

ORCID: https://orcid.org/ 0000-0002-5309-0447

Master's degree in Business Administration at Federal University of Lavras; Attending Ph.D. in Business Administration at Federal University of Lavras and in Economic Sciences at Université Paris-Saclay, CentraleSupélec, Gif-sur-Yvette, France. E-mail: assis.sthais@gmail.com

André Luiz Zambalde

ORCID: https://orcid.org/ 0000-0003-0129-7451

Ph.D. in Systems Engineering and Computing at Federal University of Rio de Janeiro; Retired Professor and Researcher at Federal University of Lavras,

Lavras - MG, Brazil. E-mail: zambaufla@gmail.com 